confidence that on the eye of man contaminated with mustard gas, this substance will act with beneficial results in the majority of cases.

We have the honour to be, Sirs,

Your obedient servants,

$$
\begin{aligned}
& \text { JNO. EYRE, } \\
& \text { FRANK W. LAW. }
\end{aligned}
$$

P.S.-As regards the late effects of mustard gas injury to the eye, though perhaps "disastrous" is not too strong a word to apply, it must be admitted that the advent of diathermy and contact glasses into this field has entirely altered the outlook in these cases, and may be said to have brought them within the range of effective treatment. (See Phillips, T. J., Proc. Roy. Soc. Med., Sect. Ophthal., Vol. XXXIII, Jan. 25, 1940.)

LoNDON, July 4, 1940.

\title{
OBITUARY
}

\section{SIR GEORGE BERRY}

Sir George Andreas Berry, LL.D., F.R.C.S.E., died at his residence, "King's Knoll," North Berwick, on June 18, in his 87 th year.

George Berry was the eldest son of Walter Berry of Glenstriven, Argyllshire. Born in 1853, he was educated at Marlborough and at Edinburgh. He studied mathematics under Professor Tait, and became one of the six members of Tait's Senior Class, where he developed his remarkable knowledge of this subject. He graduated M.B., C.M. at Edinburgh in 1876, and in 1981 became a Fellow of the Royal College of Surgeons of Edinburgh.

Before beginning practice George Berry prosecuted his special studies in ophthalmology for some years in various Universities and Hospitals. In Copenhagen he worked with his distinguished uncle, Professor Hansen Grut, who later became Bowman Lecturer of the Ophthalmological Society of the United Kingdom in 1889, and for whom he retained throughout his life the greatest admiration and regard. He also studied in France, Austria, Germany and Holland at this period of his career.

While he was House Surgeon at Moorfields Eye Hospital, London, in 1878-1879, Berry was one of the moving spirits in the formation of the Ophthalmological Society of the United Kingdom, which was founded in 1880 . Throughout his lifetime he took the greatest interest in this Society, of which he was an Original Member. 


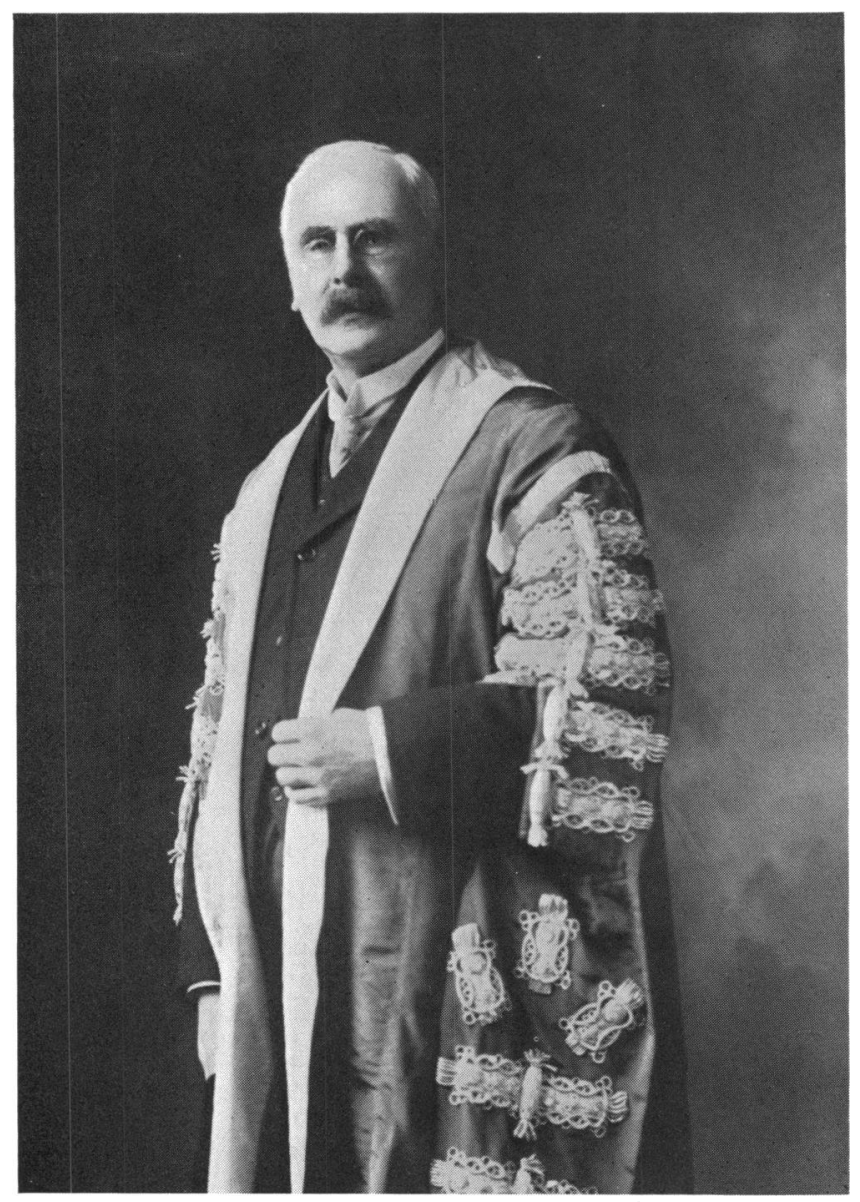

SIR GEORGE BERRY

as President of the Royal College of SURGEONS OF EDINBURGH 
While still a comparatively young man he was recognised as an authority in ophthalmology, and enjoyed a high reputation on the Continent and in America, as well as at home. He was the author of a text-book entitled: "Diseases of the Eye-A Practical Treatise for Students of Ophthalmology." This text-book was referred to by many of the leading continental Professors of Ophthalmology as being not only an exhaustive treatise, but also distinguished by many original observations and ideas. It was widely used as a standard work for many years after its publication. The second edition appeared in 1893. The terms of the dedication of this book, to Edmund Hansen Grut, M.D., show the keen appreciation, the enthusiasm and the loyalty which were essentially characteristic of Berry. All his assistants and many others who had the privilege of knowing him, recognised the magnetism of his personality, the strength of his intellect and his independent and original type of mind.

Two monographs from his pen were also much appreciated and widely used: "Subjective Symptoms in Eye Disease" and "Ophthalmoscopic Diagnosis." That on subjective symptoms, published in 1886 was especially interesting and characteristic. His interest in, and remarkable knowledge of the significance of subjective symptoms in the early diagnosis of disease proved of great value in his clinical work and teaching, which was not only stimulating and inspiring to his senior students and assistants, but also well adapted to the more junior members of his class and clinic.

He was a well known figure at the meetings of the Ophthalmological Society of the United Kingdom, and was Member of Council from 1889-1892; Vice-President from 1895-1898; and President from 1909-1911. In 1917 the Society paid him the highest honour by electing him to be Bowman Lecturer. His important contributions in discussion and his able and numerous papers which appeared in the Society's Transactions, and also elsewhere, are evidence alike of his ability, and of the lively interest which he always took in the advance of ophthalmology and in the welfare and work of the Society.

He was a member of the British Medical Associatian for many years. He was awarded the Middlemore Prize in 1886, and was Vice-President of the Section of Ophthalmology in 1889 and 1898, and President in 1905.

Berry served on the Staff of the Eye Department of the Royal Infirmary, Edinburgh, for 23 years, and retired from the position of Senior Surgeon of the Department in 1905. As Lecturer on Diseases of the Eye in the lidinburgh University, many students passed through his hands, not a few of whom have obtained distinction as oculists at home and in Overseas Dominions.

He was a Fellow of the Royal Society of Edinburgh; Honorary 
Fellow of the Royal Academy of Medicine of Ireland; President of the Royal College of Surgeons of Edinburgh from 1910 to 1912; a member of Edinburgh University Court; and a Manager of the Royal Infirmary. During the last War he established and conducted the Ophthalmic Department of the Second Scottish General Hospital, Edinburgh. He was appointed Honorary Surgeon Oculist in Scotland to H.M. King Edward VII, and to H.M. King George V, and in 1916 the honcur of Knighthood was conferred upon him. From 1922 to 1931 he was Member of Parliament (Conservative) for the Scottish Universities; at the end of which period he received the Honorary LL.D. of Edinburgh University.

Sir George Berry was a man of remarkable ability. Physically vigorous, he enjoyed outdoor sports-especially golf and angling. He was much interested in music and played the 'cello. He took a prominent part in relation to the Foundation of the Reid Chair of Music in the University of Edinburgh. His great interest in mathematics was abundantly shown in his text-book and in his contributions to this subject. He possessed a remarkable acquaintance with modern languages and especially with the less generally known Norse tongues, with which he had become familiar in early life. His brightness of mind, his scientific imagination, and high and varied attainments were fully recognised and highly valued by his colleagues, and he was much beloved by a wide circle of friends.

When he retired from a long life of high attainment and great activity, he resided at North Berwick, where he had built a house and layed out an excellent garden, in which he took great pleasure. He married in 1883, Agnes Jean, daughter of the late Sir William Muir, K.C.S.I., by whom he was predeceased; and is survived by three daughters.

With the passing of Sir George Berry only two of the original members of the Ophthalmological Society now remain, Sir Thomas Barlow and Sir Lindo Ferguson.

A. H. H. S.

\section{THOMAS SNOWBALL}

The late Mr. Thomas Snowball of Burnley was born in Huntly, Aberdeenshire, in 1873 and received his early education in that place. From there he proceeded to Aberdeen University where he graduated M.A. in 1892 and M.B., Ch.B. in 1897. Eventually deciding to study ophthalmology, he held the appointment of clinical assistant at "Moorfields" and subsequently went to Germany for further experience. He settled in practice in Burnley nearly forty years ago and had a long association with the Burnley Victoria Hospital, to which he was appointed Honorary Ophthalmic and Aural Surgeon in 1926 on the death of his partner Mr. Herbert 